\title{
農村経済研究
}

第 31 巻 第 1 号（通巻 62 号）

2013 年 6 月

\section{《論 文》}

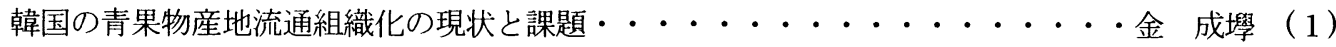

一農協中央会の経済・信用分離論の農協共販体制一の影響一

岩手県における農産物直売所の現状と 6 次産業化の展開方向に関する一考察・・・下山 禎 $(11)$

産地商人群を基盤とする農民専業合作社の現状と課題・・・・早・成田拓未・隋姝妍（18）

一中国おうとう産地を事例として一

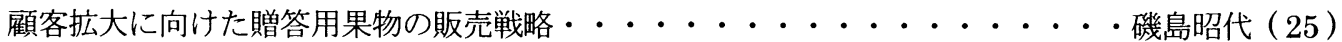

一「お寸そわけ袋」の考案と贈答用リンゴにおける活用可能性の検証-

Why Some Farmers Participate in Agricultural Cooperatives, While Others Do Not:

Evidence from Tegallega Village - Cianjur Regency, Indonesia

. . . . . Dea Christina Junissa Iman Soebrata, Nina Takashino ( 33 )

Adoption and Sustainability of New Technologies:

A Case Study of Integrated Coffee-Goat Farming in Bali

- - Dian Adi Anggraeni Elisabeth, Hitoshi Yonekura, Nina Takashino ( 39 )

有機農業経営における有機栽培稲作拡大制約への対応活動….......高橋太一 $(46)$

農村の経済外的人間関係を媒介する農地の意味に関する考察………井坂友美 $(54)$

一南沼原地区と三郷堰地区におけるインタビュー調査から一

経営マネジメントシステムとしてのG A P の機能………幸雄・吉原康弘（60）

〜 J GAPを中心としたアンケート調査結果〜

夏秋イチゴの直接取引における問題対応と取引の継続・….......龁谷美紀（67）

中国農民専業合作社における “農超対接” の現状と課題・……成田拓未・大島一二（75）

米粉用米の栽培実態と農地保全効果……… 三浦亮・渡部岳陽・佐藤了（83）

〜秋田県羽後・湯沢地域を事例に〜

消費者の年代別に見た野菜消費行動の特徵一調理に着目した接近の試み一・・・佐藤百合香 $(89)$

地域との関わりが地産地消という購買行動に与える影響

………......鶴巻なつ美・小沢瓦・藤科智海（96）

中国における食品製造副産物の利活用システムに関する事例分析

ーりんごジュース製造副産物リサイクル・システムの日中比較研究一

…….......泉谷眞実・房家垛・石塚哉史・松崎正敏（102）

中国系食品企業における対日野菜輸出の現段階と展望……石塚哉史・相良百合子（108）

一山東省産にんにく・ごぼうの事例を中心に

農産物直売所における原子力災害の影響と放射性物質検査体制……朴相賢・小松知末（115）

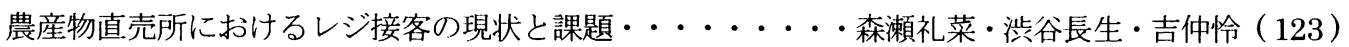

東北水田作経営における雇用導入と労務管理一秋田県中山間地域における A 法人を対象に一

…………佐藤千尋・角田毅・中村勝則・上田賢悦（129） 